\title{
Spontaneous Tension Pneumocephalus
}

\section{Pneumocéfalo Espontâneo Hipertensivo}

\author{
João Fernandes SERÔDIO ${ }^{1}$, Miguel TRINDADE ${ }^{1}$, Catarina FAVAS ${ }^{1}$ \\ Acta Med Port 2019 Dec;32(12):788-788 - https://doi.org/10.20344/amp.11591
}

\section{Keywords: Meningitis/complications; Pneumocephalus/etiology; Pneumocephalus/therapy}

Palavras-chave: Meningite/complicação; Pneumocéfalo/etiologia; Pneumocéfalo/tratamento

A 78-year-old man was hospitalized and treated for the third episode of bacterial meningitis, with no etiological agent found. The imaging study for repeated meningitis revealed right tegmen tympani cerebrospinal fluid fistula. During hospitalization he developed sudden coma with no head trauma. Brain computed tomography showed large intraventricular pneumocephalus (Fig. 1). The patient underwent external ventricular drain and fistula surgical repair. The procedure was complicated by epidural hematoma and status epilepticus. Neurological evolution was poor.

Tension pneumocephalus is defined as the presence of air within the skull leading to a rise in intracranial hypertension with rapid neurologic deterioration. ${ }^{1}$ Most cases occur due to face and head trauma or surgery, ${ }^{2}$ so the occurrence of spontaneous pneumocephalus is very rare. ${ }^{3}$ Spontaneous pneumocephalus in association with meningitis is extremely rare, is usually associated with Clostridium perfringens meningitis and rarely with mixed aerobic-anaerobic meningitis. Management relies on surgery and supportive care.

\section{PROTECTION OF HUMANS AND ANIMALS}

The authors declare that the procedures were followed according to the regulations established by the Clinical Research and Ethics Committee and to the Helsinki Declaration of the World Medical Association.

\section{DATA CONFIDENTIALITY}

The authors declare having followed the protocols in use at their working center regarding patients' data publication.

\section{INFORMED CONSENT}

Obtained.

\section{CONFLICTS OF INTEREST}

All authors report no conflict of interest.

\section{FUNDING SOURCES}

The authors declare that there were no external sources of study for the performance of this article.

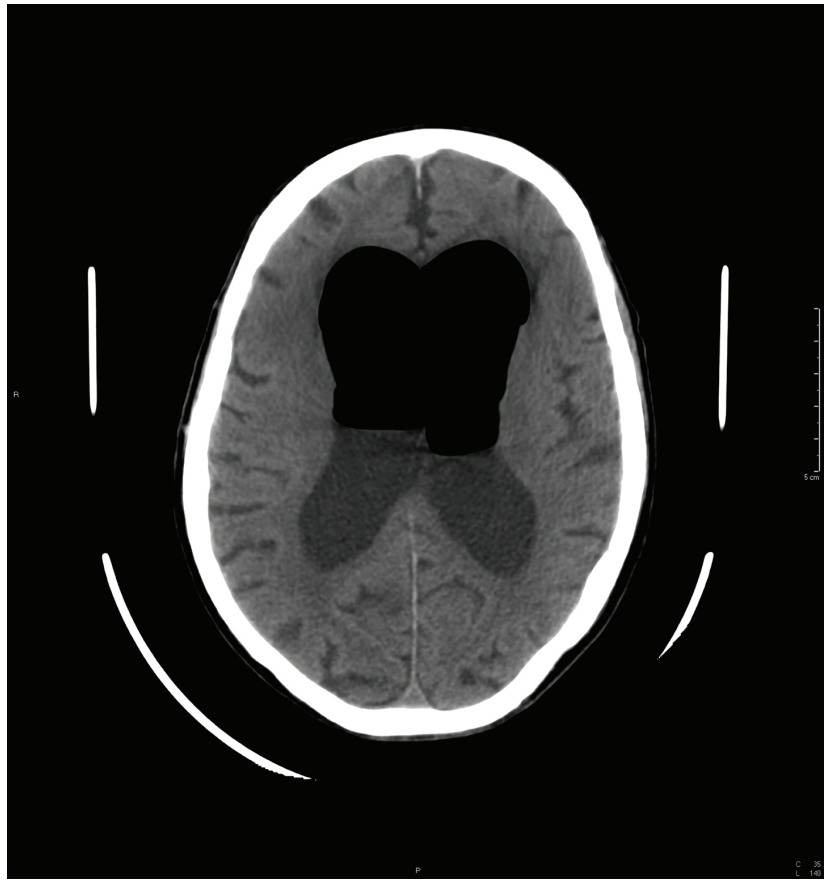

Figure 1 - Brain CT shows large intraventricular pneumocephalus with air-fluid level, enlarged lateral ventricles and thinning of the overlying cortex

\section{REFERENCES}

1. Clement AR, Palaniappan D, Panigrahi RK. Tension pneumocephalus. Anesthesiology. 2017;127:710.

2. Dabdoub CB, Salas G, Silveira Edo N, Dabdoub CF. Review of the management of pneumocephalus. Surg Neurol Int. 2015;6:155.

3. Abbati SG, Torino RR. Spontaneous intraparenchymal otogenic pneumocephalus: a case report and review of literature. Surg Neurol Int. 2012;3:32.

4. Kim KS, Kim SW, Kim SH. Spontaneous pneumocephalus caused by pneumococcal meningitis. J Korean Neurosurg Soc. 2013;53:249-251.

5. Young M, Putty M, Schaible K. Spontaneous intraventricular tension pneumocephalus: case report and review of the literature. World Neurosurg. 2018;114:317-22.

1. Serviço de Medicina IV. Hospital Prof. Doutor Fernando Fonseca. Amadora. Portugal.

$\triangle$ Autor correspondente: João Fernandes Serôdio. jserodio@campus.ul.pt

Recebido: 22 de novembro de 2018 - Aceite: 21 de fevereiro de 2019 | Copyright @ Ordem dos Médicos 2019 